\title{
Cecropin P1 inhibits porcine reproductive and respiratory syndrome virus by blocking attachment
}

\author{
Chunhe Guo ${ }^{1 \dagger}$, Yumao Huang ${ }^{2 \dagger}$, Peiqing Cong ${ }^{1}$, Xiaohong Liu', Yaosheng Chen ${ }^{1}$ and Zuyong He ${ }^{1 *}$
}

\begin{abstract}
Background: Porcine reproductive and respiratory syndrome virus (PRRSV) is a continuous threat to the pig industry, causing high economic losses worldwide. Current vaccines have specific limitations in terms of their safety and efficacy, so the development of novel antiviral drugs is urgently required. The aim of this study was to evaluate the inhibitory effects and underlying molecular mechanisms of the antimicrobial peptide cecropin P1 (CP1) against PRRSV infection in vitro.

Results: CP1 not only displayed extracellular virucidal activity against PRRSV, but also exerted a potent inhibitory effect when added either before, simultaneously with, or after viral inoculation. The inhibitory effect of CP1 occurred during viral attachment, but not at viral entry into Marc-145 cells. CP1 also inhibited viral particle release and attenuated virus-induced apoptosis during the late phase of infection. CP1 exerted similar inhibitory effects against PRRSV infection in porcine alveolar macrophages, the cells targeted by the virus in vivo during its infection of pigs. The expression of interleukin 6 was elevated by CP1 in porcine alveolar macrophages, which might contribute to its inhibition of PRRSV infection.
\end{abstract}

Conclusions: Collectively, our findings provide a new direction for the development of potential therapeutic drugs against PRRSV infection.

Keywords: Cecropin P1, PRRSV, Antiviral activity, Antimicrobial peptide

\section{Background}

Porcine reproductive and respiratory syndrome (PRRS) is one of the most economically important viral diseases in sows, causing enormous production losses in the pig industry worldwide [1]. It was first reported at the end of the 1980s in North America and Canada, and is commonly known as blue-eared pig disease [2,3]. The disease is characterized by abortion and poor reproductive performance in pregnant sows and by respiratory distress in growing pigs and piglets [4]. PRRS virus (PRRSV), the etiological agent of the disease, is an enveloped, singlestranded positive-sense RNA virus that clusters in the order Nidovirales and the family Arteriviridae, together

\footnotetext{
* Correspondence: zuyonghe@gmail.com

${ }^{\dagger}$ Equal contributors

'State Key Laboratory of Biocontrol, School of Life Sciences, Sun Yat-sen University, North Third road, Guangzhou Higher Education Mega Center, Guangzhou, Guangdong 510006, PR China

Full list of author information is available at the end of the article
}

with equine arteritis virus, lactate dehydrogenase-elevating virus, and simian hemorrhagic fever virus. The 15-kb genome of PRRSV contains a 5 '-untranslated region (UTR), nine open reading frames (ORFs 1a, 1b, 2a, 2b, and 3-7) and a 3 '-UTR [5]. The PRRSV virion consists of a nucleocapsid surrounded by a lipid envelope. Pigs persistently infected with PRRSV develop viremia and reduced cellmediated immunity [6]. Important features of PRRSV are its extreme genetic, antigenic, and immunobiological variability. Consequently, PRRSV remains the greatest challenge for the swine industry, and there is a strong demand for the development of new antiviral strategies against PRRSV infection [7].

Antimicrobial peptides are cationic and amphipathic molecules distributed widely among organisms of both the plant and animal kingdoms that display broadspectrum antimicrobial activities against bacteria, fungi, and viruses, thus acting as innate antibiotics $[8,9]$. Cecropin P1 (CP1), originally isolated from porcine intestine, is 
a low-molecular-weight peptide with antiviral activity against infectious hematopoietic necrosis virus, viral hemorrhagic septicemia virus, snakehead rhabdovirus, and infectious pancreatic necrosis virus in vitro $[10,11]$. In this study, we investigated whether CP1 inhibits PRRSV replication in vitro. Our findings show that CP1 exerted potent antiviral activity against PRRSV infection in both Marc-145 cells and porcine alveolar macrophages (PAMs). The mechanisms of CP1 were also characterized.

\section{Results}

CP1 markedly inhibits $\mathrm{CH}-1 \mathrm{a}$ infection and replication

CP1 was initially expressed and purified in Pichia pastoris (Figure 1A). Subsequently, to evaluate the in vitro antiviral activity of $\mathrm{CP} 1$ against $\mathrm{CH}-1 \mathrm{a}$ infection, immunofluorescence assay (IFA), cytopathic effect (CPE), and the 50\% tissue culture infectious dose $\left(\mathrm{TCID}_{50}\right)$ assays were performed. As shown in Figure 1B, CP1 significantly inhibited viral infection in a dose-dependent manner at $36 \mathrm{~h}$ postinfection (hpi). The number of infectious viral particles was

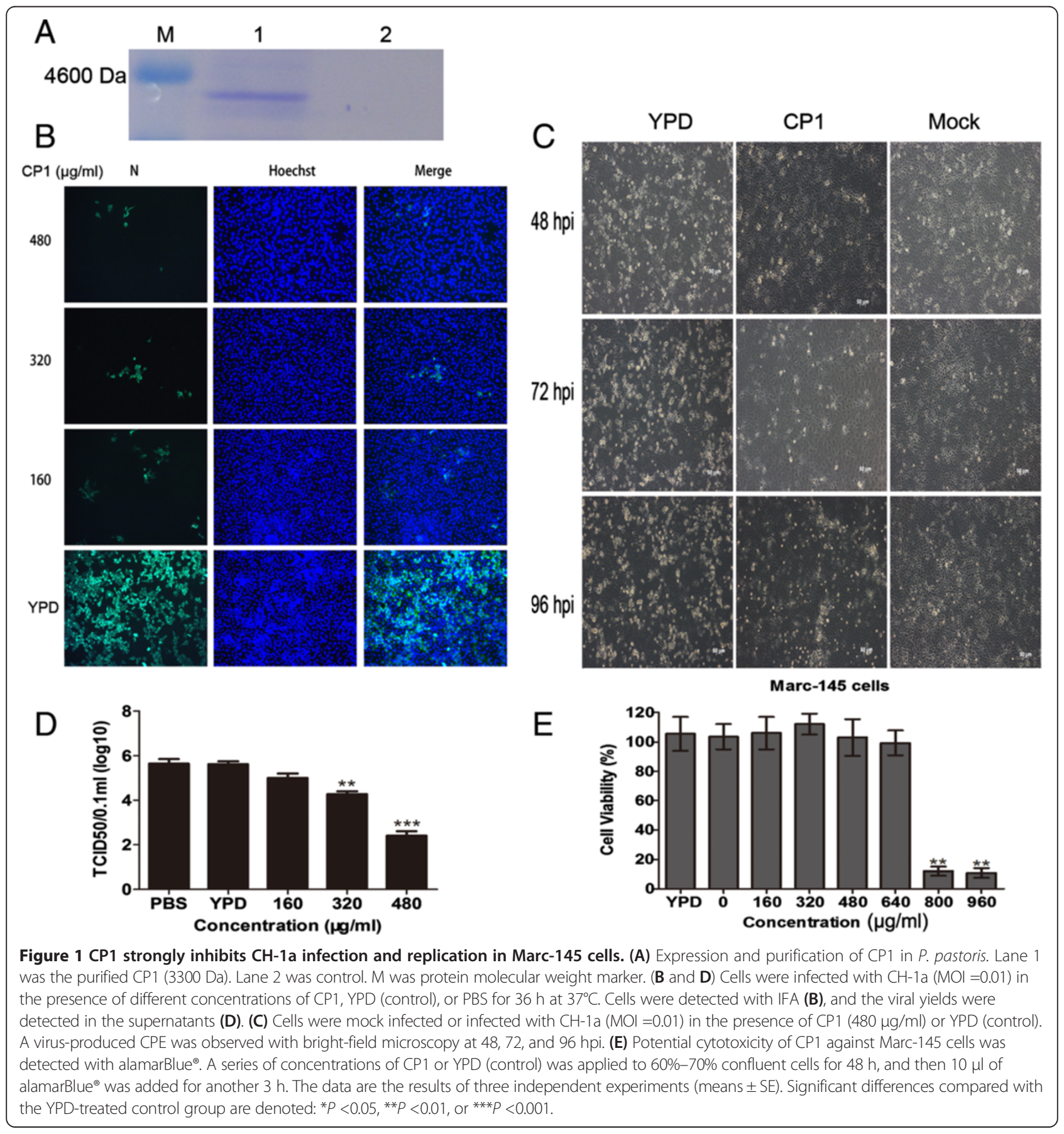


markedly reduced by $\mathrm{CP} 1$. Consistent with this, CP1 $(480 \mu \mathrm{g} / \mathrm{ml})$ notably abrogated the $\mathrm{CH}$-1a-induced CPE at 48, 72, or 96 hpi in Marc-145 cells infected with $\mathrm{CH}-1 \mathrm{a}$ at a multiplicity of infection (MOI) of 0.01 compared with the yeast extract peptone dextrose (YPD) control (Figure 1C). Furthermore, the production of viral progeny was significantly reduced at 36 hpi by $\mathrm{CP} 1$, in a dose-dependent manner (Figure 1D). CP1 inhibited $\mathrm{CH}-1 \mathrm{a}$ infection in Marc-145 cells with a $50 \%$ effective concentration $\left(\mathrm{EC}_{50}\right)$ of $112 \mu \mathrm{g} / \mathrm{ml}$. To rule out the possibility that YPD affects $\mathrm{CH}$ 1a replication, cells treated with phosphate-buffered saline (PBS) were used as another control. The results showed that YPD had no effect on viral replication (Figure 1D). To determine whether the concentration-dependent cytotoxicity of CP1 affected $\mathrm{CH}-1 \mathrm{a}$ infection and replication, a cytotoxicity assay was performed in the presence of different concentrations of CP1 or YPD (control) using alamarBlue ${ }^{\oplus}$. As shown in Figure 1E, no significant cytotoxicity was observed up to $480 \mu \mathrm{g} / \mathrm{ml} \mathrm{CP} 1$. Therefore, we performed all subsequent experiments with CP1 at a concentration no higher than $480 \mu \mathrm{g} / \mathrm{ml}$ in Marc-145 cells. The $50 \%$ cytotoxic concentration $\left(\mathrm{CC}_{50}\right)$ of $\mathrm{CP} 1$ for Marc145 cells was estimated to be $719 \mu \mathrm{g} / \mathrm{ml}$.

To verify that viral RNA transcription and protein translation are blocked by CP1 during PRRSV infection, the kinetics of $\mathrm{CH}-1$ a replication in Marc-145 cells were investigated at the indicated times after treatment with CP1 $(480 \mu \mathrm{g} / \mathrm{ml})$ or YPD (control). Cells were inoculated with $\mathrm{CH}-1 \mathrm{a}$ at an MOI of 0.1 in the presence of CP1 or YPD (control) for 6, 12, 24, 36, or $48 \mathrm{~h}$. Their total RNAs were analyzed with quantitative real-time reverse-transcription polymerase chain reaction (qRT-PCR) to determine the transcript levels of viral ORF7 after treatment. The cells treated with CP1 $(480 \mu \mathrm{g} / \mathrm{ml})$ showed a significant reduction in viral RNA at 24, 36, and 48 hpi compared with those treated with the YPD control (Figure 2A). The effects of treatment with CP1 at the viral protein level were analyzed with three different approaches, as described in the Methods. As shown in Figure 2C-E, compared with the YPD control, the expression of the viral $\mathrm{N}$ protein was depressed significantly reduced by $\mathrm{CP} 1$ when administered with either the pre-, co-, or posttreatment method. A virucidal assay was performed to investigate the direct inactivation effect of CP1. As shown in Figure 2B, CP1 effectively inactivated the $\mathrm{CH}-1 \mathrm{a}$ virions at $36 \mathrm{hpi}$. Taken together, these data indicate that CP1 exerts a potent extracellular virucidal activity and an inhibitory effect on $\mathrm{CH}-1 \mathrm{a}$ infection in vitro.

\section{$\mathrm{CP} 1$ blocks $\mathrm{CH}-1$ a-induced apoptosis during the late phase of infection}

Previous studies have shown that PRRSV stimulates antiapoptotic pathways in Marc-145 cells and PAMs early in infection, and that PRRSV-infected cells die from apoptosis late in infection [12]. To examine whether CP1 attenuates virus-induced apoptosis during the late phase of infection, an annexin V fluorescein isothiocyanate (FITC)/propidium iodide (PI) assay was performed. CP1 notably reduced the number of apoptotic cells compared with cells treated with the YPD control (Figure 3A and 3B). The inhibitory effects of $\mathrm{CP} 1$ on apoptosis were confirmed by the levels of caspase 3 transcripts in the virus-infected cells treated with $\mathrm{CP} 1$ for $72 \mathrm{~h}$ (Figure 3C). Together, these results indicate that $\mathrm{CP} 1$ blocks $\mathrm{CH}$-1a-virus-induced apoptosis during the late phase of infection, which might contribute to the inhibition of PRRSV infection.

\section{CP1 inhibits viral particle release}

To investigate whether CP1 reduces viral particle release, an assay described previously [13] was performed to quantify the viral particles in both the cells and the supernatant. Marc-145 cells were treated as described in the Methods. At each time point, the numbers of intracellular particles in cells treated with different concentrations of CP1 were similar to those in cells treated with YPD (control) (Figure 4A). In contrast, significantly fewer infectious viral particles were released into the supernatant by cells treated with CP1 $(480 \mu \mathrm{g} / \mathrm{ml})$ for $4 \mathrm{~h}$ than by YPD-treated cells (Figure $4 \mathrm{~B}$ ). The viral titers in the supernatants showed a similar pattern after treatment with CP1 $(480 \mu \mathrm{g} / \mathrm{ml})$ for $4 \mathrm{~h}$ (Figure $4 \mathrm{C}$ ). Taken together, these data indicate that CP1 $(480 \mu \mathrm{g} / \mathrm{ml})$ inhibits $\mathrm{CH}-1$ a particle release.

\section{$\mathrm{CP} 1$ blocks viral attachment during the $\mathrm{CH}-1$ a life cycle in Marc-145 cells}

To characterize the molecular mechanism underlying the antiviral activity of $\mathrm{CP} 1$ against $\mathrm{CH}-1 \mathrm{a}$ and to identify the stage of the viral life cycle interrupted by CP1, a viral attachment assay was performed to test whether CP1 blocks $\mathrm{CH}-1$ a attachment to Marc-145 cells. CP1 significantly reduced the transcript levels of viral ORF7 in CP1-treated cells during the period of viral attachment (Figure 5A). Consistent with these findings, the $\mathrm{N}$ protein levels of $\mathrm{CH}-1$ a were blocked by $480 \mu \mathrm{g} / \mathrm{ml} \mathrm{CP1}$ (Figure 5B). These data suggest that CP1 markedly reduces the number of infectious viral particles that attach to the cell membrane.

Previous studies have shown that PRRSV is internalized from the Marc-145 cell surface within 3-6 h [14,15]. Therefore, we investigated whether CP1 also acts at the entry stage of the viral life cycle. The kinetics of the antiviral activity of $\mathrm{CP} 1$ against $\mathrm{CH}-1$ a were analyzed with time-of-addition assays. CP1 had little effect on the viral titers and protein levels when it was added immediately after the temperature shift (Figure 5C and 5D). Consistent with these findings, no inhibitory effect was observed when CP1 was added at 2 (Figure 5E) or $4 \mathrm{~h}$ (Figure 5F) 


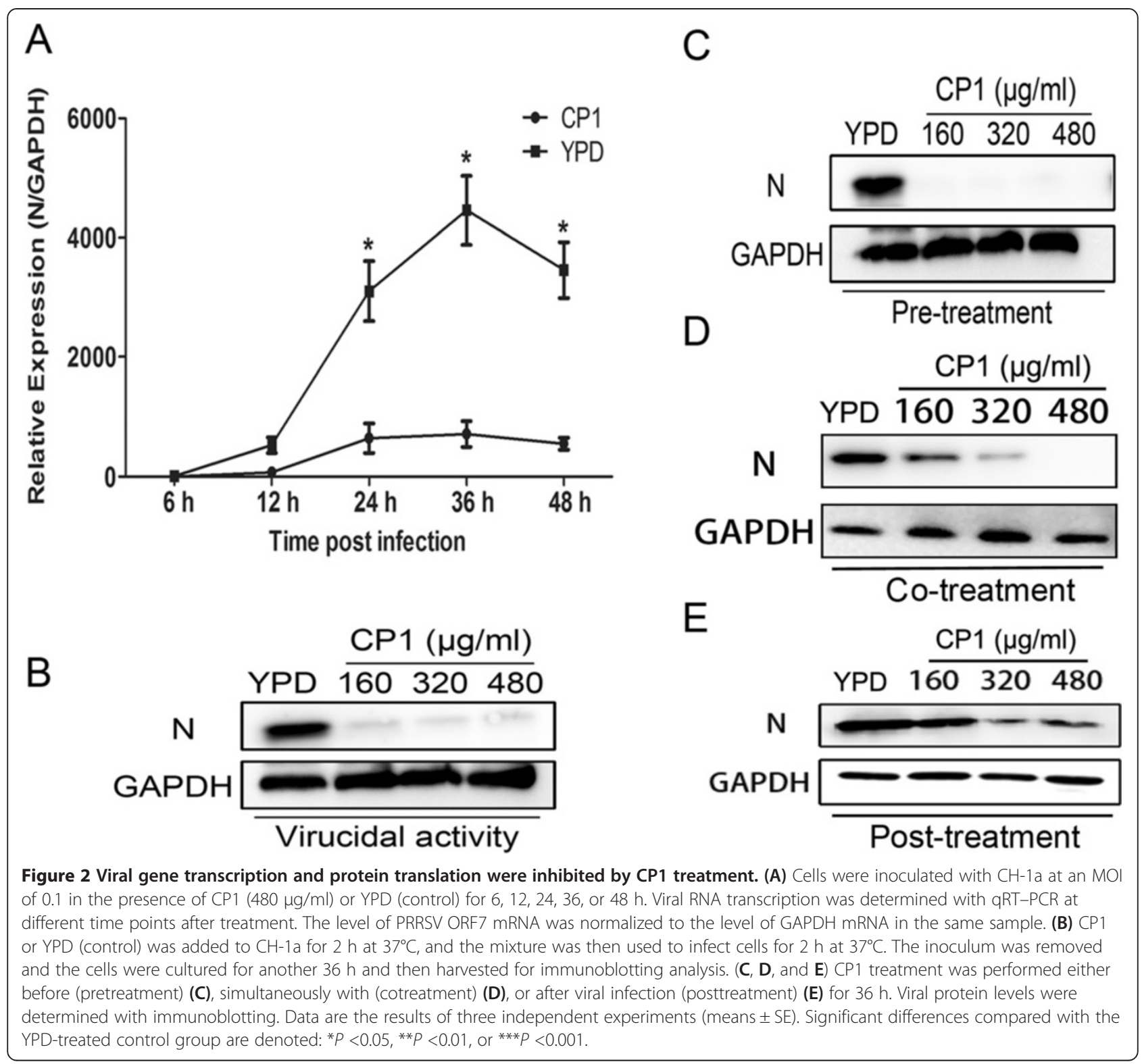

after the cells were shifted to $37^{\circ} \mathrm{C}$. Taken together, these data indicate that $\mathrm{CP} 1$ blocks the viral attachment process rather than entry process in Marc-145 cells.

\section{$\mathrm{CP} 1$ strongly inhibits $\mathrm{CH}-1$ a replication and partially elevates} cytokine expression in PAMs

Because CP1 effectively inhibited $\mathrm{CH}-1 \mathrm{a}$ infection and replication in Marc-145 cells, we investigated whether CP1 inhibits $\mathrm{CH}-1$ a replication in PAMs, the major target cell type of PRRSV infection in pigs in vivo. We initially evaluated its effect on $\mathrm{CH}-1$ a replication in PAMs. As shown in Figure 6B-D, CP1 caused significant reductions in the viral $\mathrm{N}$ protein at the transcript and protein levels and in the viral titers at $36 \mathrm{hpi}$, compared with those of cells treated with the YPD control. CP1 inhibited $\mathrm{CH}-1 \mathrm{a}$ infection of PAMs with an $\mathrm{EC}_{50}$ of $65 \mu \mathrm{g} / \mathrm{ml}$. To exclude the possibility that $\mathrm{CP} 1$ exerts a nonspecific toxicity that affected PAM viability and thus affected $\mathrm{CH}-1$ a replication, cytotoxicity assays were performed in the presence of different concentrations of CP1 or YPD (control) for $48 \mathrm{~h}$ using alamarBlue ${ }^{\oplus}$ CP1 was noncytotoxic at concentrations up to $280 \mu \mathrm{g} / \mathrm{ml}$ (Figure $6 \mathrm{~A}$ ). The $\mathrm{CC}_{50}$ of CP1 for PAMs was estimated to be $551 \mu \mathrm{g} / \mathrm{ml}$.

To further characterize the innate immune response induced by CP1 in PAMs, the expression of IL-6, IFN- $\alpha$, IFN- $\beta$, and TGF- $\beta 1$ was analyzed in the presence of CP1 or YPD (control) in virus-infected or uninfected cells. CP1 significantly enhanced the expression of IL-6 in virusinfected and uninfected cells, which would help to initiate the adaptive immune response. More importantly, the 


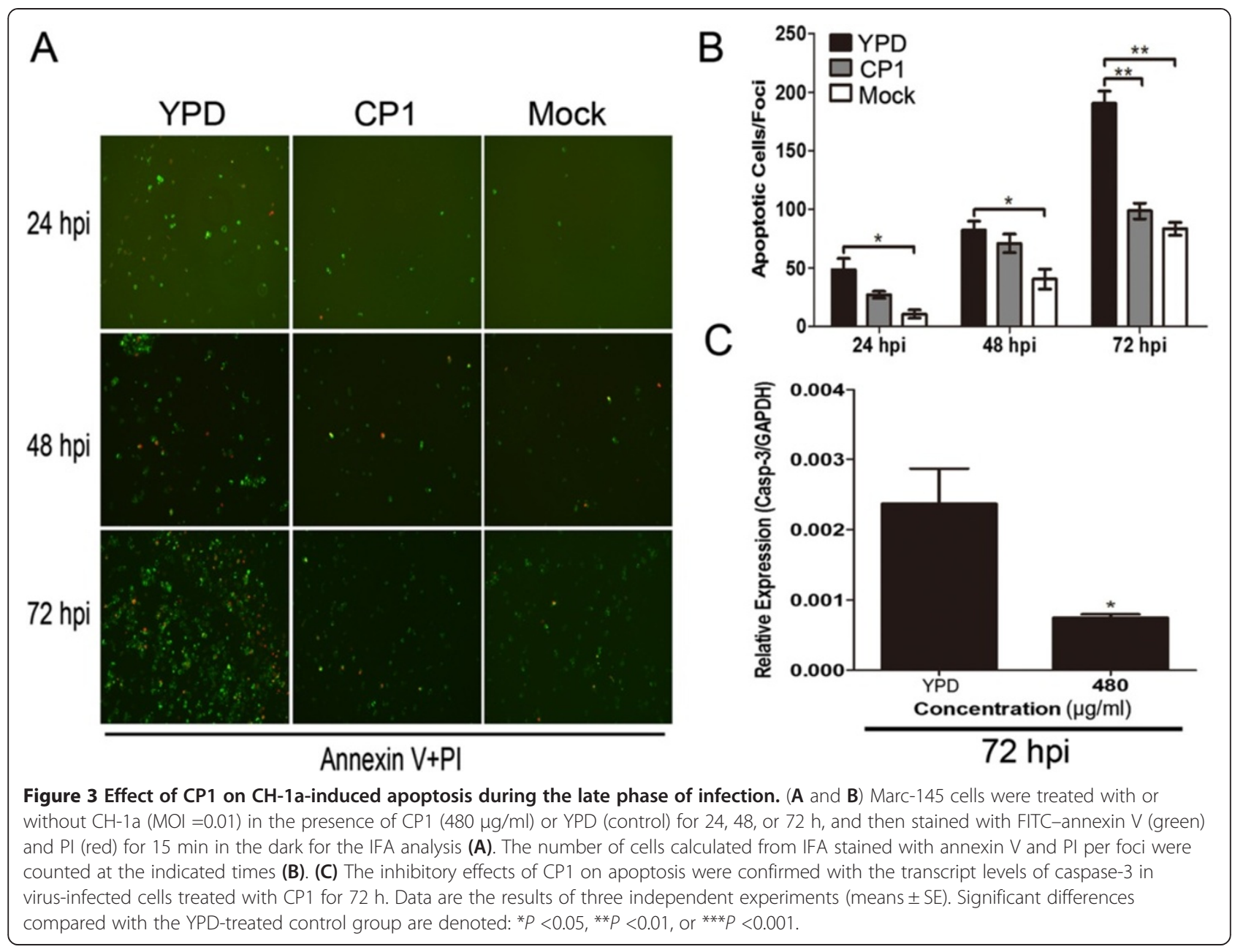

expression of IL-6 was significantly increased in CP1treated $\mathrm{CH}-1 \mathrm{a}$-infected cells compared with its expression in cells treated with $\mathrm{CH}-1 \mathrm{a}$ and YPD or YPD alone (Figure 6E). However, CP1 did not significantly induce the expression of IFN- $\alpha$ (Figure $6 \mathrm{~F}$ ), IFN- $\beta$ (Figure 6G), or TGF- $\beta 1$ (Figure $6 \mathrm{H}$ ) in PAMs. Taken together, these data show that CP1 partially induces cytokine expression in PAMs, which might contribute to the inhibition of PRRSV infection.

\section{Discussion}

PRRSV first emerged in the late 1980s in North America, and subsequently in Europe, causing huge economic losses. It has since spread across the globe, inducing characteristic severe reproductive failure in female pigs and respiratory tract illness in piglets $[16,17]$. PRRSV infection causes the delayed appearance and low titers of neutralizing antibodies, and a weak cell-mediated immune response [18]. This allows the infection to persist and the prevalence of PRRSV infection is still high in the swine industry worldwide. Moreover, current vaccines are losing their power with the antigenic variability and genetic drift of the virus $[19,20]$. Therefore, there is an urgent need for safer and more effective strategies to control PRRSV. CP1 is a 31-residue peptide, originally isolated from porcine intestine, with a basic $\mathrm{N}$-terminus connected to a neutral C-terminus by a glycine-proline link [21,22]. It displays antibacterial and antiviral properties in fish species important to aquaculture [11]. To our knowledge, this is the first study to report the extracellular virucidal activity and inhibitory effects of CP1 against PRRSV infection and replication in vitro, with no cytotoxicity (Figures 1, 2, and 6). CP1 inhibited PRRSV infection with an $\mathrm{EC}_{50}$ of $112 \mu \mathrm{g} / \mathrm{ml}$ in Marc-145 cells and $65 \mu \mathrm{g} / \mathrm{ml}$ in PAMs. CP1 also displays antibacterial activity against Escherichia coli strains DH5 $\alpha$, TOP10, and K88, Staphylococcus aureus strain Cowan I, and Streptococcus zooepidemicus strain C55138 (data not shown).

In this study, we have shown that CP1 potently blocked $\mathrm{N}$-PRRSV strain $\mathrm{CH}-1 \mathrm{a}$ replication at multiple points in the viral life cycle, impairing RNA and protein synthesis and viral particle release in Marc-145 cells (Figures 2 and 4). More importantly, an antiviral assay based on three different methods of administration showed that pre- and 


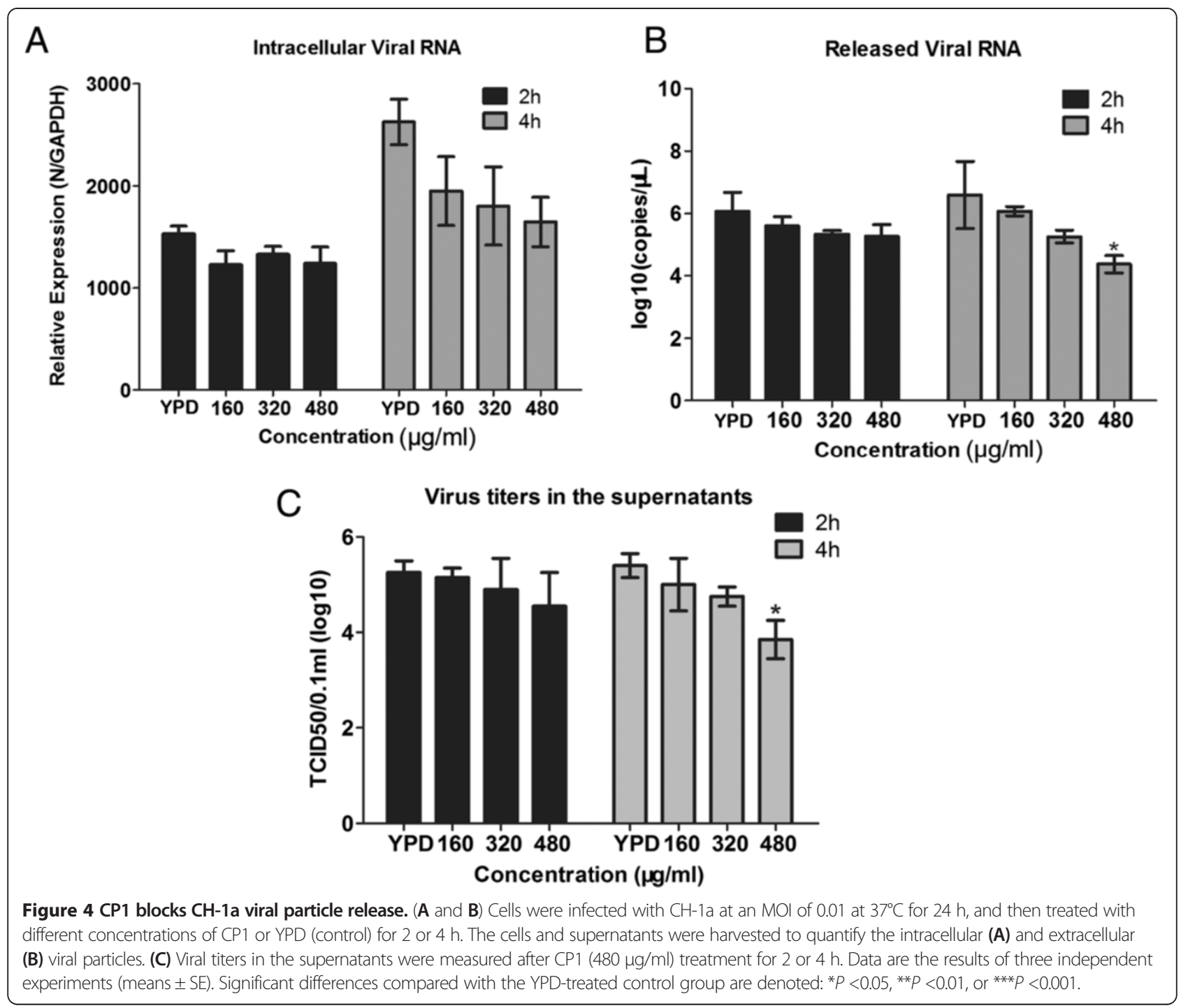

cotreatments with $\mathrm{CP1}$ (Figure 2C and 2D) produced robust antiviral activity and were more effective against $\mathrm{CH}$ 1a infection than CP1 posttreatment (Figure 2E), which is consistent with previous research [23]. This suggests that CP1 has potent inhibitory activity against the initial stages of viral infection, including the viral attachment step, or directly destroys the viral particles. Therefore, we investigated the direct inactivation of the virus by $\mathrm{CP} 1$ and found that $\mathrm{CP} 1$ has a potent virucidal activity against $\mathrm{CH}-1 \mathrm{a}$ infection in vitro (Figure 2B). Further research should be undertaken to clarify the molecular mechanism of the virucidal activity of CP1.

Previously studies have shown that antimicrobial peptides, such as $\theta$-defensin, bind to the glycoprotein B protein of herpes simplex virus type $1(\mathrm{HSV}-1)$ with high affinity and then protect cells from $\mathrm{HSV}-1$ infection by blocking viral attachment and entry [24]. In this study, we identified the molecular mechanisms underlying the
CP1-mediated inhibition of $\mathrm{CH}-1$ a in vitro. Binding and entry assays in Marc-145 cells showed that CP1 prevents viral adsorption during the viral life cycle (Figure 5), thus disrupting the initial step of viral entry into the target cells, and suggesting that the interaction between the virus and its receptors on the cell membrane is blocked by CP1. However, further studies are required to determine how $\mathrm{CP} 1$ affects the attachment of viral particles to the cell membrane. Because Marc145 cells are not of porcine origin but are monkey cells [25], we also tested the antiviral activity of CP1 in PAMs, which are known to be the primary host cell target for PRRSV replication in vivo. CP1 exhibited robust antiviral activity in PAMs (Figure 6B-D), suggesting that it might be an effective inhibitor of PRRSV infection in vivo. CP1 also partially elevated cytokine expression (IL-6), which should induce the innate immune response in PAMs (Figure 6E). 


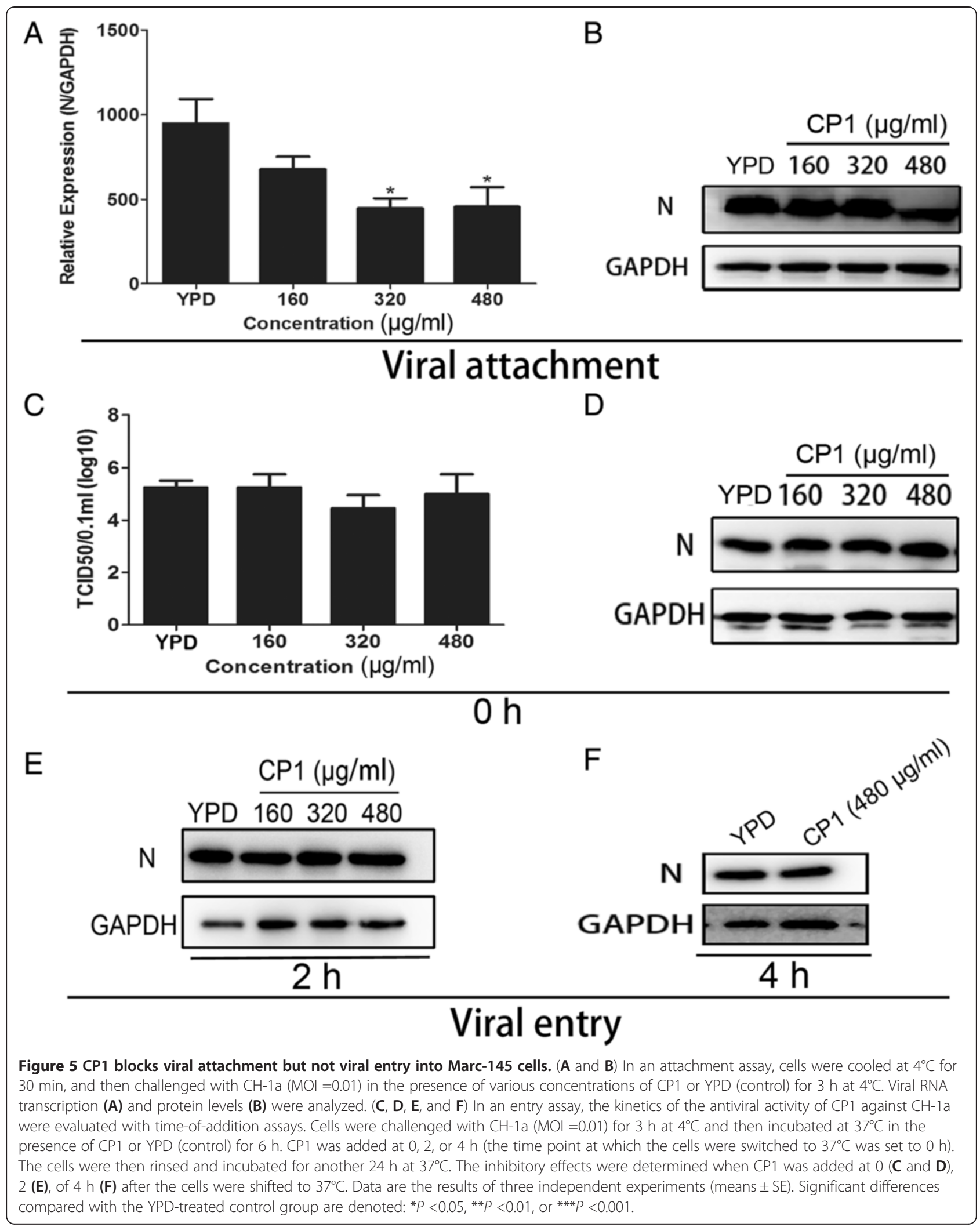




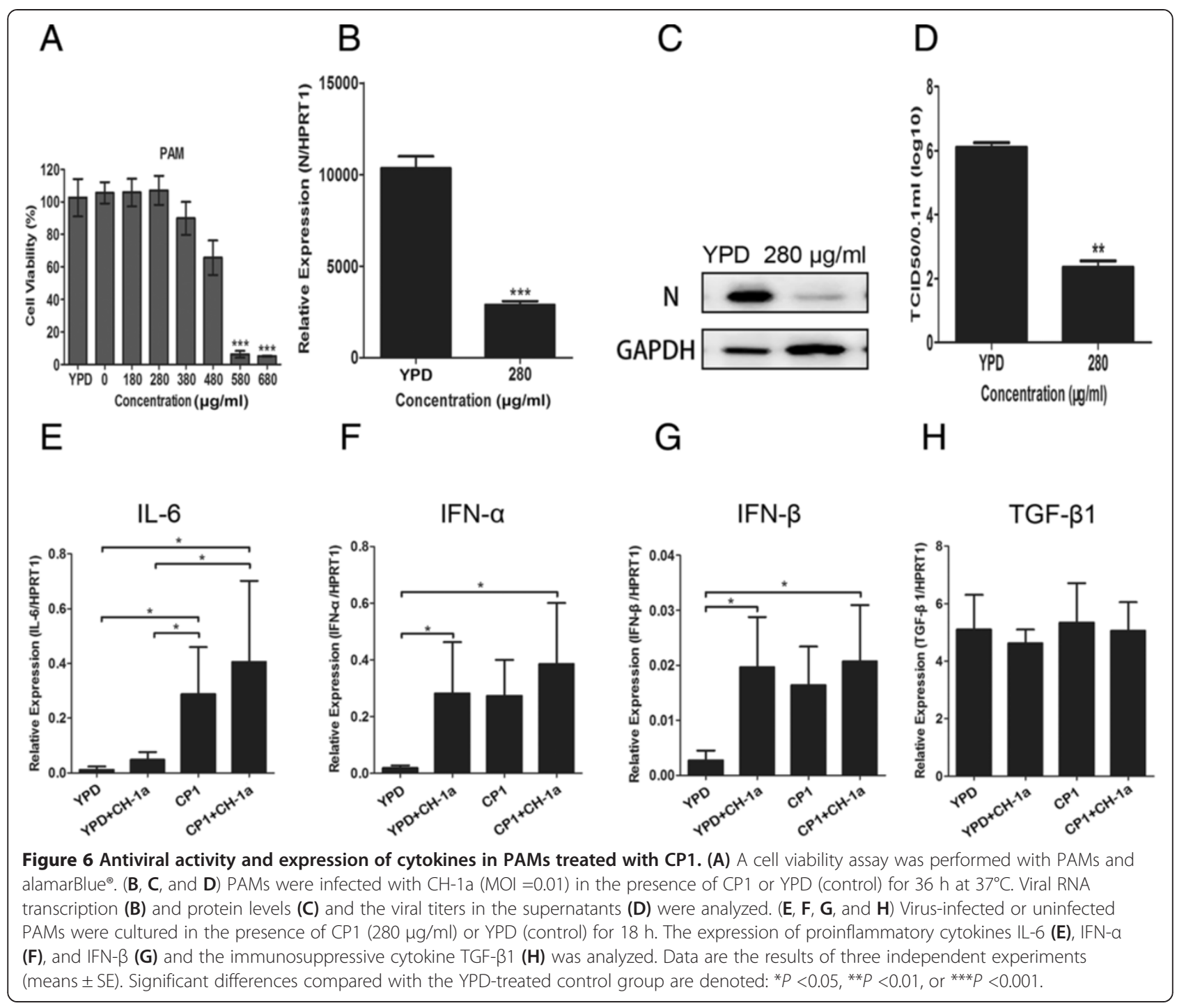

\section{Conclusions}

In summary, our findings reveal for the first time that CP1 not only has extracellular virucidal activity, but also exerts a potent inhibitory effect on PRRSV infection and replication in vitro, when administered as a pre-, co-, or posttreatment. Therefore, $\mathrm{CP} 1$ is an excellent candidate for the development of future antiviral strategies against PRRSV infection. Further research is required to evaluate the potential in vivo antiviral activity of CP1 in animal models.

\section{Methods}

\section{Cells and viruses}

Marc-145 cells were grown in Dulbecco's modified Eagle's medium (DMEM) with 10\% heat-inactivated fetal bovine serum (FBS; PAA, Pasching, Austria). PAMs were obtained with lung lavage from the lungs of 3-8-weekold PRRSV-negative piglets [26] and cultured in RPMI-1640 supplemented with $10 \% \mathrm{FBS}, 100 \mathrm{U} / \mathrm{ml}$ penicillin, and $100 \mu \mathrm{g} / \mathrm{ml}$ streptomycin sulfate at $37^{\circ} \mathrm{C}$ in $5 \% \mathrm{CO} 2$. All animal experiments were approved by the Institutional Animal Care and Use Committee of Sun Yat-sen University. Classical North American type PRRSV (N-PRRSV) strain $\mathrm{CH}-1 \mathrm{a}$, kindly provided by Dr. Guihong Zhang of South China Agricultural University, was propagated and titered in Marc-145 cells or PAMs and used throughout the study.

\section{Expression and purification of CP1 in Pichia pastoris}

The CP1 gene (GenBank: AB186032.1) was cloned into the expression vector pGAPZaA (Invitrogen) and expressed in Pichia pastoris strain SMD1168 (Invitrogen) using the Easyselect ${ }^{\text {tox }}$ Pichia Expression Kit (Invitrogen), according to the manufacturer's instructions. Briefly, the recombinant plasmid pGAPZaA-CP1, confirmed by restriction enzyme digestion, PCR, and sequencing, was transformed into 
strain SMD1168 with electroporation. The CP1 polypeptide was expressed from the highest-expressing Pichia pastoris clone in $10 \mathrm{~mL}$ of yeast extract peptone dextrose (YPD) at $30^{\circ} \mathrm{C}$ with shaking at $250 \mathrm{rpm}$ until the optical density at $600 \mathrm{~nm}\left(\mathrm{OD}_{600}\right)$ was 2 . An aliquot $(0.1 \mathrm{ml})$ of this culture was used to inoculate $50 \mathrm{ml}$ of YPD in a $250 \mathrm{ml}$ flask, which was then incubated at $30^{\circ} \mathrm{C}$ with shaking at $250 \mathrm{rpm}$. The $6 \times$ His-tagged target protein was purified with Ni-NTA agarose (Invitrogen), according to the manufacturer's protocol. The concentration of the purified recombinant $\mathrm{CP} 1$ was determined relative to a bovine serum albumin (BSA) standard using the BCA Protein Assay Kit (Pierce). The purified protein was stored in YPD.

\section{Cytotoxicity assay}

The potential cytotoxicity of CP1 was measured with the alamarBlue ${ }^{\bullet}$ Assay (Invitrogen), according to the manufacturer's instructions. Briefly, a series of concentrations of CP1, diluted in DMEM or YPD (control), was applied to $60 \%-70 \%$ confluent Marc-145 cells or PAMs. After incubation for $48 \mathrm{~h}$ at $37^{\circ} \mathrm{C}$ in a $5 \% \mathrm{CO}_{2}$ atmosphere, $10 \mu \mathrm{l}$ of alamarBlue $^{\oplus}$ was added and the cultures were incubated for another $3 \mathrm{~h}$. Fluorescence intensity was measured at $570 \mathrm{~nm}$ excitation and $590 \mathrm{~nm}$ emission wavelengths and compared with the control values. The $\mathrm{CC}_{50}$ was analyzed with the GraphPad Prism software (version 5.0).

\section{Quantitative real-time reverse-transcription polymerase chain reaction ( $q R T-P C R$ )}

Total RNA was extracted from Marc-145 cells or PAMs with TRIzol Reagent (Invitrogen), according to the manufacturer's instructions, and subjected to qRT-PCR analysis. The reverse transcription of RNA and qPCR were conducted as previously described [27,28]. All samples were run in triplicate. Serial 10-fold dilutions of the $\mathrm{CH}$ 1a ORF7 fragment, which encodes the viral $\mathrm{N}$ protein, were used to construct a standard curve. Specific primers for the quantitative analysis of mRNAs were designed and are listed in Table 1.

\section{Immunoblotting}

Marc-145 cells or PAMs were seeded in six-well plates and harvested in lysis buffer containing $1 \mathrm{mM}$ phenylmethylsulfonyl fluoride (Beyotime), and an immunoblotting analysis was performed as previously described [29]. The cell lysates were separated with $10 \%$ sodium dodecyl sulfate polyacrylamide gel electrophoresis, and then electroblotted onto pre-equilibrated polyvinylidene difluoride membranes (Millipore). After the membranes were blocked with 5\% nonfat dry milk in TBST (20 mM Tris [pH 7.5], $150 \mathrm{mM}$ $\mathrm{NaCl}, 0.5 \%$ Tween 20) for $2 \mathrm{~h}$ at $37^{\circ} \mathrm{C}$, they were rinsed and incubated with an anti-PRRSV $\mathrm{N}$ protein monoclonal antibody (SDOW17), anti-glyceraldehyde phosphate dehydrogenase (GAPDH) antibody (Cell Signaling Technology),
Table 1 List of primers for real-time PCR

\begin{tabular}{|c|c|}
\hline Primer $^{\#}$ & Sequences $\left(5^{\prime}-3^{\prime}\right)$ \\
\hline ORF7(N)-F & AAAACCAGTCCAGAGGCAAG \\
\hline ORF7(N)-R & CGGATCAGACGCACAGTATG \\
\hline mGAPDH-F & TGACAACAGCCTCAAGATCG \\
\hline mGAPDH-R & GTCTTCTGGGTGGCAGT GAT \\
\hline mCaspase-3-F & ATGTCCGGGATCTGGGTTCT \\
\hline mCaspase-3-R & CTAGGTCAAGCTTTCATTCT \\
\hline pHPRT1-F & TGGAAAGAATGTCTTGATTGTTGAAG \\
\hline pHPRT1-R & ATCTTTGGATTATGCTGCTTGACC \\
\hline plL-6-F & AATGTCGAGGCTGTGCAGATT \\
\hline plL-6-R & TGGTGGCTTTGTCTGGATTCT \\
\hline pTGF- $\beta 1-F$ & AGGGCTACCATGCCAATTTCT \\
\hline pTGF- $\beta 1-R$ & CCGGGTTGTGCTGGTTGT \\
\hline plFN-a-F & TCCAGCTCTTCAGCACAGAG \\
\hline plFN-a-R & AGCTGCTGATCCAGTCCAGT \\
\hline plFN- $\beta-F$ & GGAGACAATCCTGGAGGAAAT \\
\hline plFN- $\beta-R$ & TTCAGGTGAAGAATGGTCATGT \\
\hline
\end{tabular}

"F: forward primer, R: reverse primer. The " $\mathrm{m}$ " prior to a primer name indicates it is for a monkey gene, and the " $p$ " prior to a primer name indicates it is for a porcine gene.

horseradish-peroxidase-conjugated anti-mouse IgG antibody (Santa Cruz), and anti-rabbit IgG antibody (Cell Signaling Technology). The signals were detected using ECL reagent (Pierce, Rockford, USA).

\section{Immunofluorescence assay (IFA)}

The cells were fixed with $4 \%$ paraformaldehyde and permeabilized with $0.3 \%$ Triton X-100 at room temperature, and then blocked with $1 \%$ BSA in PBS, after which they were rinsed three times with PBS. After incubation for $30 \mathrm{~min}$, anti-PRRSV $\mathrm{N}$ protein $\mathrm{mAb}$ (SDOW17) and FITCconjugated anti-mouse IgG secondary antibody in PBS containing $1 \%$ BSA were added sequentially and incubated for another $2 \mathrm{~h}$ after each addition. The nuclei were stained with Hoechst dye 33258 (Sigma-Aldrich, St. Louis, MO, USA). The cells were rinsed and observed with fluorescence microscopy (Carl Zeiss, Jena, Germany).

\section{Virucidal assay}

CP1 at the indicated concentrations or YPD (control) was preincubated with $\mathrm{CH}-1 \mathrm{a}$ for $2 \mathrm{~h}$ at $37^{\circ} \mathrm{C}$. The mixtures were then diluted and added to $60 \%-70 \%$ confluent Marc145 cells. After incubation for $2 \mathrm{~h}$ at $37^{\circ} \mathrm{C}$, the mixtures were removed. Cells were replenished with fresh DMEM containing $2 \% \mathrm{FBS}$ and cultured for another $36 \mathrm{~h}$ at $37^{\circ} \mathrm{C}$, and then harvested for immunoblotting analysis.

\section{Antiviral assay}

Marc-145 cells were seeded in six-well plates and grown to $60 \%-70 \%$ confluence at $37^{\circ} \mathrm{C}$ in $5 \% \mathrm{CO}_{2}$. The effects 
of treatment with CP1 were analyzed with three different approaches. (I) Pretreatment: cells were treated with CP1 or YPD (control) for $2 \mathrm{~h}$ and then infected with $\mathrm{CH}-1 \mathrm{a}$ $(\mathrm{MOI}=0.01)$ for $36 \mathrm{~h}$. (II) Cotreatment: cells were inoculated simultaneously with $\mathrm{CH}-1 \mathrm{a}(\mathrm{MOI}=0.01)$ and $\mathrm{CP} 1$ or YPD (control) for $36 \mathrm{~h}$. (III) Posttreatment: cells were inoculated with $\mathrm{CH}-1 \mathrm{a}(\mathrm{MOI}=0.01)$ for $8 \mathrm{~h}$ at $37^{\circ} \mathrm{C}$, and then the viral inoculum was removed and fresh DMEM medium supplemented with $2 \%$ FBS and containing various concentrations of CP1 or YPD (control) was added. The cells were then incubated for a further $36 \mathrm{~h}$. The supernatants were collected to titrate the viral yields, and the viral titers were determined as TCID $_{50}$ [27]. The cells were harvested for IFA, qRT-PCR, and immunoblotting analysis. The concentration that reduced the CPE by $50 \%$ relative to the viral control was estimated with the GraphPad Prism software (version 5.0), and was defined as $\mathrm{EC}_{50}$.

\section{Apoptosis assay}

Apoptosis was evaluated with an annexin V-FITC/PI assay (BD Biosciences Pharmingen). Marc-145 cells were challenged with $\mathrm{CH}-1 \mathrm{a}(\mathrm{MOI}=0.01)$ in the presence of CP1 $(480 \mu \mathrm{g} / \mathrm{ml})$ or YPD (control) for 24,48 , or $72 \mathrm{~h}$. Apoptosis was then measured with annexin V-FITC/PI staining, according to the manufacturer's protocol. The cells were then analyzed with fluorescence microscopy (Carl Zeiss).

\section{Viral release assay}

Marc-145 cells were seeded in six-well plates, grown to $60 \%-70 \%$ confluence, and infected with $\mathrm{CH}-1 \mathrm{a}$ at an MOI of 0.01 at $37^{\circ} \mathrm{C}$ for $24 \mathrm{~h}$. The cells were then treated with different concentrations of CP1 or YPD (control), and washed three times with PBS. After incubation for 2 or $4 \mathrm{~h}$, the supernatants and cells were harvested to quantify the extracellular and intracellular viral particles, respectively, with qRT-PCR.

\section{Binding and entry assays}

Binding and entry assays were performed as previously described, with modifications [30,31]. For the binding assay, Marc-145 cells were cooled at $4^{\circ} \mathrm{C}$ for $30 \mathrm{~min}$, and then challenged with $\mathrm{CH}-1 \mathrm{a}(\mathrm{MOI}=0.01)$ in the presence of various concentrations of CP1 or YPD (control) for $3 \mathrm{~h}$ at $4^{\circ} \mathrm{C}$. After the cells were rinsed three times with ice-cold PBS, they were incubated at $37^{\circ} \mathrm{C}$ for another $24 \mathrm{~h}$. The cell lysates were prepared for qRT-PCR and immunoblotting analysis.

For the entry assay, Marc-145 cells were initially challenged with $\mathrm{CH}-1 \mathrm{a}(\mathrm{MOI}=0.01)$ for $3 \mathrm{~h}$ at $4^{\circ} \mathrm{C}$. After the cells were rinsed three times with ice-cold PBS, they were cultured at $37^{\circ} \mathrm{C}$ in the presence of various concentrations of CP1 or YPD (control) for $6 \mathrm{~h}$. CP1 was added at 0,2 , or $4 \mathrm{~h}$ after the temperature shift (the time point at which the cells were switched to $37^{\circ} \mathrm{C}$ was set to $0 \mathrm{~h}$ ). The cells were then rinsed three times with PBS and incubated for another $24 \mathrm{~h}$ at $37^{\circ} \mathrm{C}$. The supernatants were harvested for virus titration and the cells were collected for immunoblotting analysis.

\section{Cytokine mRNA expression}

The expression of cytokines in PAMs was determined. Virus-infected or uninfected cells were cultured in the presence of CP1 $(280 \mu \mathrm{g} / \mathrm{ml})$ or YPD (control) for $18 \mathrm{~h}$, and the expression of proinflammatory cytokines interleukin 6 (IL-6), interferon $\alpha$ (IFN- $\alpha$ ), and IFN- $\beta$, and the immunosuppressive cytokine transforming growth factor $\beta 1$ (TGF- $\beta 1$ ) was then quantified with qRT-PCR. Specific primers designed for the quantitative analysis of the mRNAs are listed in Table 1.

\section{Statistical analysis}

All experiments were performed with at least three independent replicates. Data were analyzed with the SPSS 16.0 and GraphPad Prism software (version 5.0) and are expressed as means \pm standard errors (SE). Student's $t$ test and one-way analysis of variance were used. $P$ values $<0.05$ were considered statistically significant.

\section{Competing interests}

The authors declare that they have no competing interests.

\section{Authors' contributions}

CG and YH conceived and designed the study. CG performed the experiments, analyzed the data, and drafted the manuscript. $C G, Y H, P C, X L$, $Y C$, and $\mathrm{ZH}$ coordinated the study. $\mathrm{ZH}$ and $\mathrm{YC}$ contributed to the interpretation of the data and took part in the critical revision of the manuscript. All authors have read and approved the final manuscript.

\section{Acknowledgments}

This work was supported by the China Agriculture Research System (CASR-36) and the China Spark Program (2011GA781001).

\section{Author details}

${ }^{1}$ State Key Laboratory of Biocontrol, School of Life Sciences, Sun Yat-sen University, North Third road, Guangzhou Higher Education Mega Center Guangzhou, Guangdong 510006, PR China. 'College of Veterinary Medicine, South China Agricultural University, Guangzhou, Guangdong 510642, PR China.

Received: 12 June 2014 Accepted: 23 October 2014

Published online: 18 November 2014

\section{References}

1. Van Breedam W, Van Gorp H, Zhang JQ, Crocker PR, Delputte PL, Nauwynck HJ: The M/GP(5) glycoprotein complex of porcine reproductive and respiratory syndrome virus binds the sialoadhesin receptor in a sialic acid-dependent manner. PLOS Pathog 2010, 6(1):e1000730.

2. Wensvoort G, Terpstra C, Pol JM, ter Laak EA, Bloemraad M, de Kluyver EP, Kragten C, van Buiten L, den Besten A, Wagenaar F, Broekhuijsen JM, Moonen PL, Zetstra T, de Boer EA, Tibben HJ, de Jong MF, van't Veld P, Greenland GJ, van Gennep JA, Voets MT, Verheijden JH, Braamskamp J: Mystery swine disease in The Netherlands: the isolation of Lelystad virus. Vet Q 1991, 13(3):121-130.

3. Zhao C, Liu S, Li C, Yang L, Zu Y: In vitro evaluation of the antiviral activity of the synthetic epigallocatechin gallate analog-epigallocatechin gallate (EGCG) palmitate against porcine reproductive and respiratory syndrome virus. Viruses 2014, 6(2):938-950. 
4. Kuzemtseva L, de la Torre E, Martin G, Soldevila F, Ait-Ali T, Mateu E, Darwich L: Regulation of toll-like receptors 3, 7 and 9 in porcine alveolar macrophages by different genotype 1 strains of porcine reproductive and respiratory syndrome virus. Vet Immunol Immunopathol 2014, 158(3-4):189-198.

5. Johnson CR, Griggs TF, Gnanandarajah J, Murtaugh MP: Novel structural protein in porcine reproductive and respiratory syndrome virus encoded by an alternative ORF5 present in all arteriviruses. J Gen Virol 2011, 92(Pt 5):1107-1116.

6. Hu J, Ni Y, Dryman BA, Meng XJ, Zhang C: Immunogenicity study of plantmade oral subunit vaccine against porcine reproductive and respiratory syndrome virus (PRRSV). Vaccine 2012, 30(12):2068-2074.

7. Wang L, Xiao S, Gao J, Liu M, Zhang X, Li M, Zhao G, Mo D, Liu X, Chen Y: Inhibition of replication of porcine reproductive and respiratory syndrome virus by hemin is highly dependent on heme oxygenase-1, but independent of iron in MARC-145 cells. Antiviral Res 2014, 105:39-46.

8. Park CH, Valore EV, Waring AJ, Ganz T: Hepcidin, a urinary antimicrobial peptide synthesized in the liver. J Biol Chem 2001, 276(11):7806-7810.

9. Peters BM, Shirtliff ME, Jabra-Rizk MA: Antimicrobial peptides: primeval molecules or future drugs? PLoS Pathog 2010, 6(10):e1001067.

10. Chiou PP, Lin CM, Perez L, Chen TT: Effect of cecropin B and a synthetic analogue on propagation of fish viruses in vitro. Mar Biotechnol (NY) 2002, 4(3):294-302.

11. Chiou PP, Chen MJ, Lin CM, Khoo J, Larson J, Holt R, Leong JA, Thorgarrd G, Chen $T$ : Production of homozygous transgenic rainbow trout with enhanced disease resistance. Mar Biotechnol (NY) 2014, 16(3):299-308.

12. Costers S, Lefebvre DJ, Delputte PL, Nauwynck HJ: Porcine reproductive and respiratory syndrome virus modulates apoptosis during replication in alveolar macrophages. Arch Virol 2008, 153(8):1453-1465.

13. Kumar N, Liang YH, Parslow TG, Liang YY: Receptor tyrosine kinase inhibitors block multiple steps of influenza a virus replication. J Virol 2011, 85(6):2818-2827.

14. Jourdan SS, Osorio FA, Hiscox JA: Biophysical characterisation of the nucleocapsid protein from a highly pathogenic porcine reproductive and respiratory syndrome virus strain. Biochem Biophys Res Commun 2012, 419(2):137-141.

15. Music N, Gagnon CA: The role of porcine reproductive and respiratory syndrome (PRRS) virus structural and non-structural proteins in virus pathogenesis. Anim Health Res Rev 2010, 11(2):135-163.

16. Pejsak Z, Stadejek T, Markowska-Daniel I: Clinical signs and economic losses caused by porcine reproductive and respiratory syndrome virus in a large breeding farm. Vet Microbiol 1997, 55(1-4):317-322.

17. Neumann EJ, Kliebenstein JB, Johnson CD, Mabry JW, Bush EJ, Seitzinger $\mathrm{AH}$, Green AL, Zimmerman JJ: Assessment of the economic impact of porcine reproductive and respiratory syndrome on swine production in the United States. J Am Vet Med Assoc 2005, 227(3):385-392.

18. Xiao ZG, Batista L, Dee S, Halbur P, Murtaugh MP: The level of virus-specific T-cell and macrophage recruitment in porcine reproductive and respiratory syndrome virus infection in pigs is independent of virus load. J Virol 2004, 78(11):5923-5933.

19. Murtaugh MP, Xiao ZG, Zuckermann F: Immunological responses of swine to porcine reproductive and respiratory syndrome virus infection. Viral Immunol 2002, 15(4):533-547.

20. Thanawongnuwech $\mathrm{R}$, Suradhat S: Taming PRRSV: revisiting the control strategies and vaccine design. Virus Res 2010, 154(1-2):133-140.

21. Moore AJ, Beazley WD, Bibby MC, Devine DA: Antimicrobial activity of cecropins. J Antimicrob Chemother 1996, 37(6):1077-1089.

22. Zhou YL, Peng Y: Synergistic effect of clinically used antibiotics and peptide antibiotics against gram-positive and gram-negative bacteria. Exp Ther Med 2013, 6(4):1000-1004

23. Hoffmann J, Schneider C, Heinbockel L, Brandenburg K, Reimer R, Gabriel G: A new class of synthetic anti-lipopolysaccharide peptides inhibits influenza A virus replication by blocking cellular attachment. Antiviral Res 2014, 104:23-33.

24. Yasin B, Wang W, Pang M, Cheshenko N, Hong T, Waring AJ, Herold BC, Wagar EA, Lehrer Rl: Theta defensins protect cells from infection by herpes simplex virus by inhibiting viral adhesion and entry. J Virol 2004, 78(10):5147-5156.

25. Zhang L, Liu J, Bai J, Du Y, Wang X, Liu X, Jiang P: Poly(l:C) inhibits porcine reproductive and respiratory syndrome virus replication in MARC-145 cells via activation of IFIT3. Antiviral Res 2013, 99(3):197-206.
26. Qiao SL, Feng LL, Bao DK, Guo JQ, Wan B, Xiao ZJ, Yang SZ, Zhang GP: Porcine reproductive and respiratory syndrome virus and bacterial endotoxin act in synergy to amplify the inflammatory response of infected macrophages. Vet Microbiol 2011, 149(1-2):213-220.

27. Delogu I, Pastorino B, Baronti C, Nougairede A, Bonnet E, de Lamballerie X: In vitro antiviral activity of arbidol against Chikungunya virus and characteristics of a selected resistant mutant. Antiviral Res 2011, 90(3):99-107.

28. Patel D, Stein DA, Zhang YJ: Morpholino oligomer-mediated protection of porcine pulmonary alveolar macrophages from arterivirus-induced cell death. Antivir Ther 2009, 14(7):899-909.

29. Hudjetz B, Gabriel G: Human-like PB2 627 K influenza virus polymerase activity is regulated by importin-alpha1 and -alpha7. PLoS Pathog 2012, 8(1):e1002488

30. Yang Q, Gao L, Si J, Sun Y, Liu J, Cao L, Feng WH: Inhibition of porcine reproductive and respiratory syndrome virus replication by flavaspidic acid AB. Antiviral Res 2013, 97(1):66-73.

31. Hong W, Li T, Song Y, Zhang R, Zeng Z, Han S, Zhang X, Wu Y, Li W, Cao Z: Inhibitory activity and mechanism of two scorpion venom peptides against herpes simplex virus type 1. Antiviral Res 2014, 102:1-10.

\section{doi:10.1186/s12866-014-0273-8}

Cite this article as: Guo et al:: Cecropin P1 inhibits porcine reproductive and respiratory syndrome virus by blocking attachment. $B M C$

Microbiology 2014 14:273.

\section{Submit your next manuscript to BioMed Central and take full advantage of:}

- Convenient online submission

- Thorough peer review

- No space constraints or color figure charges

- Immediate publication on acceptance

- Inclusion in PubMed, CAS, Scopus and Google Scholar

- Research which is freely available for redistribution 